\title{
ANALISIS PENGARUH RASIO LIKUIDITAS, EFISIENSI OPERASI, DAN RASIO SOLVABILITAS TERHADAP KINERJA KEUANGAN PADA PT BANK MAYBANK INDONESIA TbK PERIODE 2010-2018
}

\author{
Alma Aprilia *) \\ Nina Woelan Soebroto $* *)$ \\ *)almaaprilia022@gmail.com
}

\begin{abstract}
This study aims to analyze the significance of the effect of liquidity ratios, operating efficiency, and solvency ratios both simultaneously and partially on financial performance at PT Bank Maybank Indonesia Tbk. period of 2010-2018. The population in this study is liquidity ratio, operating efficiency, and solvency ratio. The sampling technique using simple random sampling method, obtained samples in this study as many as 3 variables, namely Loan to Deposit Ratio (LDR), Operational Costs compared to Operating Income (BOPO), and Capital Adequacy Ratio (CAR). The data used in this study are secondary data obtained from published quarterly financial reports. The model of analysis used is Multiple Linear Regression, while the data analysis technique uses $F$ Test, Determination Coefficient (Adjusted $R^{2}$ ), and $t$ Test. The results of the analysis and discussions show that the variable Loan to Deposit Ratio (LDR), Operational Cost versus Operating Income (BOPO), and Capital Adequacy Ratio (CAR) simultaneously have significant effects on Return On Assets (ROA) at PT Bank Maybank Indonesia Tbk. the period of 2010-2018. Partially, the Loan to Deposit Ratio (LDR) variable has negative and not significant effect on Return On Assets (ROA), while Operational Cost versus Operational Income (BOPO) variables partially have a negative and significant effect on Return On Assets (ROA), as well as variables Capital Adequacy Ratio (CAR) partially has a negative and significant effect on Return On Assets (ROA) at PT Bank Maybank Indonesia Tbk. the period 2010-2018.
\end{abstract}

Keywords : Financial Performance, Liquidity Ratio, Operating Efficiency, Solvability Ratio.

*) Mahasiswa Tugas Akhir Prodi Keuangan dan Perbankan, Jurusan Akuntansi, Politeknik Negeri Semarang

**) Dosen Jurusan Akuntansi, Politeknik Negeri Semarang

\section{PENDAHULUAN}

\section{Latar Belakang Masalah}

Bank sebagai salah satu lembaga keuangan nasional memiliki peranan penting yang strategis untuk mendukung pelaksanaan pembangunan nasional di Indonesia. Sebagaimana yang tercantum dalam Pasal 1 Ayat 2 Undang-Undang Republik Indonesia Nomor 10 Tahun 1998 Tentang Perubahan Atas Undang-Undang Nomor 7 Tahun 1992 Tentang Perbankan, dijelaskan bahwa bank adalah badan usaha yang menghimpun dana dari masyarakat dalam bentuk simpanan dan menyalurkannya kepada masyarakat dalam bentuk kredit dan atau bentuk-bentuk lainnya dalam rangka meningkatkan taraf hidup rakyat banyak.

Saat ini, perkembangan di dunia perbankan sangat pesat dan tingkat persaingan yang tinggi dapat mempengaruhi performa suatu bank. Untuk menjaga agar aktivitas perbankan 
tetap eksis maka bank diminta untuk menjaga kinerjanya setiap periode. Penilaian terhadap kinerja suatu bank dapat dilakukan dengan melihat laporan keuangannya. Selain itu informasi mengenai laporan keuangan dapat membantu para stakeholder untuk menilai kondisi keuangan perbankan. Melihat betapa pentingnya laporan keuangan tersebut, maka perbankan wajib mempublikasikan laporan keuangannya secara berkala.

Tujuan akhir yang ingin dicapai oleh suatu perusahaan yang terpenting adalah memperoleh laba atau keuntungan yang maksimal, disamping hal-hal lainnya. Untuk mengukur tingkat keuntungan suatu perusahaan, digunakan rasio keuntungan atau rasio profitabilitas yang dikenal juga dengan nama rasio rentabilitas (Kasmir, 2010:196). Sama halnya dengan penelitian yang dilakukan oleh Hutagalung, et al (2013) yang menyatakan bahwa profitabilitas merupakan indikator yang paling tepat untuk mengukur kinerja suatu bank. Profitabilitas merupakan kemampuan perusahaan untuk memperoleh laba selama periode tertentu (Munawir, 2010:33). Ukuran profitabilitas yang digunakan dalam penelitian ini adalah Return On Assets (ROA) karena Bank Indonesia lebih mengutamakan nilai profitabilitas suatu bank yang diukur dengan aset yang dananya sebagian besar berasal dari simpanan masyarakat (Dendawijaya, 2009:119).

Kemampuan bank dalam mengelola likuiditasnya akan berdampak terhadap kepercayaan masyarakat kepada bank itu sendiri sehingga akan membantu kelangsungan operasional maupun keberadaan bank tersebut (Prasetyo dan Darmayanti, 2015). Oleh karena itu bank wajib menyediakan likuiditas tersebut dengan cukup dan mengelolanya dengan baik, karena apabila likuiditas tersebut terlalu kecil maka akan mengganggu kegiatan operasional bank, namun jika jumlah likuiditas terlalu besar maka akan menurunkan efisiensi bank sehingga berdampak pada rendahnya tingkat profitabilitas. Rasio likuiditas yang digunakan dalam penelitian ini adalah Loan To Deposit Ratio (LDR).

Untuk meminimalkan risiko-risiko yang harus dihadapi perbankan guna mempertahankan kinerjanya, maka perbankan perlu bertindak rasional dalam arti lebih memperhatikan masalah efisiensi. Dengan adanya efisiensi pada lembaga perbankan terutama efisiensi biaya maka akan diperoleh tingkat keuntungan yang optimal, penambahan jumlah dana yang disalurkan, dan tingkat kesehatan perbankan yang meningkat. Untuk mengukur efisiensi operasi dalam penelitian ini digunakan Biaya Operasional dibandingkan Pendapatan Operasional (BOPO).

Kinerja bank yang baik dapat terlihat dari kemampuan manajemen yang mengelolanya termasuk dalam memenuhi kewajiban jangka panjang. Analisis rasio solvabilitas adalah analisis yang digunakan untuk mengukur kemampuan bank dalam memenuhi kewajiban jangka 
panjangnya atau kemampuan bank untuk memenuhi kewajiban-kewajiban jika terjadi likuidasi bank (Dendawijaya, 2009:120). Rasio ini selanjutnya dihubungkan dengan pemenuhan kecukupan modal minimum karena modal digunakan sebagai penyangga terhadap kemungkinan kerugian dan menjaga kepercayaan terhadap aktivitas perbankan dalam menjalankan fungsinya sebagai lembaga intermediasi atas dana yang diterima dari nasabah. Untuk mengukur kecukupan modal menggunakan Capital Adequacy Ratio (CAR).

Kinerja PT Bank Maybank Indonesia Tbk selama 2010-2018 diketahui bahwa ROA PT Bank Maybank Indonesia Tbk selama 9 tahun berturut-turut mengalami fluktuasi. Pada tahun 2010 ke tahun 2011 ROA cenderung stabil. Di tahun 2012 ROA mengalami kenaikan dari yang sebelumnya 1,31 menjadi 1,64. Namun ROA mengalami penurunan di tahun 2013 menjadi 1,42. Selanjutnya di tahun 2014 ROA mengalami penurunan yang signifikan menjadi 0,48. Sampai tahun 2015 ROA masih rendah dan hanya mengalami kenaikan sebesar 0,04. Kemudian di tahun-tahun selanjutnya ROA berhasil mengalami kenaikan. Namun di tahun 2018 ROA kembali mengalami penurunan menjadi 1,23. Hal ini menunjukkan bahwa Maybank Indonesia belum mampu untuk mempertahankan kinerja keuangannya. Penurunan ini didukung dengan adanya publikasi dari Infobank News tertanggal 03 September 2018 yang menyatakan penurunan laba pada semester 1 di tahun 2018.

Penelitian-penelitian mengenai Return On Asset (ROA) pernah dilakukan beberapa penelitian terdahulu. Prasetyo dan Darmayanti (2015) dan Dewi et al (2015) menyatakan bahwa Loan To Deposit Ratio (LDR) berpengaruh positif dan signifikan terhadap Return On Assets (ROA). Muin (2017), Hutagalung et al (2013), dan Sudiyatno dan Fatmawati (2013) menyatakan bahwa Biaya Operasional dibandingkan Pendapatan Operasional (BOPO) berpengaruh negatif dan signifikan terhadap Return On Assets (ROA). Margaretha dan Letty (2017), Ovami (2017), dan Anggreni dan Suardhika (2014) menyatakan bahwa Capital Adequacy Ratio (CAR) berpengaruh positif dan signifikan terhadap Return On Asset (ROA). Sementara itu hasil penelitian yang dilakukan Lubis et al (2017), Fadjar et al (2013) dan M. Muh. Sabir et al (2012) menunjukkan Loan To Deposit Ratio (LDR) berpengaruh negatif dan signifikan terhadap Return On Assets (ROA). M. Muh. Sabir et al (2012) menunjukkan bahwa BOPO tidak berpengaruh terhadap ROA. Sementara Prasetyo dan Darmayanti (2015) dan Hutagalung et al (2013) menyatakan bahwa Capital Adequacy Ratio (CAR) tidak berpengaruh signifikan terhadap Return On Asset (ROA).

Berdasarkan fenomena bisnis dan research gap yang telah diuraikan, maka permasalahan dalam penelitian ini yaitu untuk mengetahui pengaruh dari rasio likuiditas yang mengacu pada Loan To Deposit Ratio (LDR), efisiensi operasi berdasarkan Biaya Operasional dibandingkan 
Pendapatan Operasional (BOPO), dan rasio solvabilitas yang mengacu pada Capital Adequacy Ratio (CAR) terhadap kinerja keuangan bank yang dilihat melalui Return On Asset (ROA).

\section{Rumusan Masalah dan Tujuan Penelitian}

Berdasarkan uraian yang telah dijabarkan di dalam latar belakang, masalah dalam penelitian ini adalah bagaimanakah pengaruh variabel-variabel Loan To Deposit Ratio (LDR), Biaya Operasional dibandingkan Pendapatan Operasional (BOPO), dan Capital Adequacy Ratio (CAR) baik secara simultan maupun secara parsial terhadap Return On Asset (ROA) pada PT Bank Maybank Indonesia Tbk. periode 2010-2018?

Sedangkan, tujuan dari penelitian ini adalah untuk membuktikan secara empiris bahwa variabel-variabel Loan To Deposit Ratio (LDR), Biaya Operasional dibandingkan Pendapatan Operasional (BOPO), dan Capital Adequacy Ratio (CAR) baik secara simultan maupun secara parsial berpengaruh signifikan terhadap Return On Asset (ROA) pada PT Bank Maybank Indonesia Tbk. periode 2010-2018.

\section{KAJIAN TEORI}

\section{Profitabilitas}

Dalam penentuan tingkat kesehatan suatu bank, Bank Indonesia lebih mementingkan penilaian besarnya Return On Assets (ROA) dan tidak memasukkan unsur Return On Equity (ROE). Hal ini dikarenakan Bank Indonesia, lebih mengutamakan nilai profitabilitas suatu bank yang diukur dengan aset yang dananya sebagian besar berasal dari dana simpanan masyarakat (Dendawijaya, 2009:119).

Menurut Dendawijaya (2009:118) Return On Assets (ROA) merupakan rasio yang digunakan untuk mengukur kemampuan manajemen bank dalam memperoleh keuntungan (laba) secara keseluruhan. Bank Indonesia menyatakan bahwa Return On Assets memiliki tujuan untuk mengukur tingkat kemampuan laba bank atas aset yang dimiliki.

Dalam Lampiran 14 Surat Edaran Bank Indonesia No 13/30/DPNP tanggal 16 Desember 2011, Return On Assets (ROA) dirumuskan :

$$
\mathrm{ROA}=\frac{\text { Laba sebelum Pajak }}{\text { Rata }- \text { rata Total Aset }} \times 100 \%
$$

\section{Rasio Likuiditas}

Analisis rasio likuiditas adalah analisis yang dilakukan terhadap kemampuan bank dalam memenuhi kewajiban-kewajiban jangka pendeknya atau kewajiban yang sudah jatuh tempo (Dendawijaya, 2009:114). 
Menurut Dendawijaya (2009:114) terdapat beberapa rasio likuiditas yang sering dipergunakan dalam menilai kinerja suatu bank antara lain sebagai berikut.

\section{Cash Ratio}

Cash ratio adalah rasio alat likuid terhadap dana pihak ketiga yang dihimpun bank yang harus segera dibayar. Cash ratio dapat dirumuskan sebagai berikut.

$$
\text { Cash Ratio }=\frac{\text { Alat likuid }}{\text { Pinjaman yang Harus Segera Dibayar }} \times 100
$$

\section{Reserve Requirement (RR)}

Reserve Requirement (RR) atau likuiditas wajib minimum adalah suatu simpanan minimum yang wajib dipelihara dalam bentuk giro di Bank Indonesia bagi semua bank. Untuk mengetahui besarnya reserve requirement dapat menggunakan perbandingan berikut.

$$
\mathrm{RR}=\frac{\text { Jumlah Alat likuid }}{\text { Jumlah Dana (Simpanan) Pihak Ketiga }} \times 100
$$

3. Loan to Deposit Ratio (LDR)

Loan to Deposit Ratio (LDR) adalah rasio antara seluruh jumlah kredit yang diberikan bank dengan dana yang diterima oleh bank. Rasio ini digunakan untuk mengukur kemampuan bank tersebut apakah mampu membayar hutang-hutangnya dan membayar kembali kepada deposannya, serta dapat memenuhi permintaan kredit yang diajukan. Atau dengan kata lain seberapa jauh pemberian kredit kepada nasabah kredit dapat mengimbangi kewajiban bank untuk segera memenuhi permintaan deposan yang ingin menarik kembali uangnya yang telah digunakan oleh bank untuk memberikan kredit (Dendawijaya, 2009:116).

Dalam Lampiran 14 Surat Edaran Bank Indonesia No 13/30/DPNP tanggal 16 Desember 2011, Loan to Deposit Ratio (LDR) diformulasikan sebagai berikut.

$$
\text { LDR }=\frac{\text { Kredit }}{\text { Dana Pihak Ketiga }} \times 100 \%
$$

\section{Loan to Asset Ratio (LAR)}

Loan to Asset Ratio (LAR) adalah rasio yang digunakan untuk mengukur tingkat likuiditas bank yang menunjukkan kemampuan bank dalam memenuhi kebutuhan kredit dengan menggunakan total asset yang dimiliki bank. Rasio loan to asset ratio dapat dirumuskan sebagai berikut.

$$
\text { LAR }=\frac{\text { Jumlah Kredit yang Diberikan }}{\text { Jumlah Asset }} \times 100 \%
$$


5. Rasio kewajiban bersih call money

Presentase dari rasio ini menunjukkan besarnya kewajiban bersih call money terhadap aktiva lancar atau aktiva yang paling likuid dari bank. Rasio kewajiban bersih call money dapat dirumuskan sebagai berikut.

Rasio Kewajiban Bersih Call Money $=\frac{\text { Kewajiban Bersih Call Money }}{\text { Aktiva Lancar }} \times 100 \%$

\section{Efisiensi Operasi}

Efisiensi operasi menunjukkan tingkat pengeluaran biaya untuk keperluan operasional bank. Rasio Biaya Operasional dibandingkan Pendapatan Operasional (BOPO) digunakan sebagai pengukur efisiensi operasi bertujuan untuk mengukur kemampuan pendapatan operasional bank dalam menutup biaya operasionalnya.

Biaya Operasional dibandingkan Pendapatan Operasional (BOPO) dapat dirumuskan sebagai berikut :

$$
\mathrm{BOPO}=\frac{\text { Biaya }(\text { Beban }) \text { Operasional }}{\text { Pendapatan Operasional }} \times 100 \%
$$

\section{Rasio Solvabilitas}

Analisis rasio solvabilitas adalah analisis yang digunakan untuk mengukur kemampuan bank dalam memenuhi kewajiban jangka panjangnya atau kemampuan bank untuk memenuhi kewajiban-kewajiban jika terjadi likuidasi bank (Dendawijaya, 2009:120). Menurut Dendawijaya (2009:120) terdapat beberapa rasio solvabilitas antara lain sebagai berikut.

1. Capital Adequacy Ratio (CAR)

Menurut Kuncoro dan Suhardjono (2011:519) Capital Adequacy Ratio (CAR) merupakan kecukupan modal yang menunjukkan kemampuan bank dalam mempertahankan modal yang mencukupi dan kemampuan manajemen bank dalam mengidentifikasi, mengukur, mengawasi, dan mengontrol risiko-risiko yang timbul yang dapat berpengaruh terhadap besarnya modal bank.

CAR merupakan indikator terhadap kemampuan bank untuk menutupi penurunan aktivanya sebagai akibat dari kerugian-kerugian bank yang disebabkan oleh aktiva yang berisiko.

Dalam Lampiran 14 Surat Edaran Bank Indonesia No 13/30/DPNP tanggal 16 Desember 2011, Capital Adequacy Ratio dapat dirumuskan sebagai berikut.

$$
\mathrm{CAR}=\frac{\text { Modal }}{\mathrm{ATMR}} \times 100 \%
$$




\section{Debt to Equity Ratio (DER)}

Debt to equity ratio adalah rasio yang digunakan untuk mengukur kemampuan bank dalam menutup sebagian atau seluruh utang-utangnya dengan dana yang berasal dari modal bank sendiri. Rasio ini dapat dirumuskan sebagai berikut.

$$
\text { DER }=\frac{\text { Jumlah Utang }}{\text { Jumlah Modal Sendiri }} \times 100 \%
$$

3. Long term debt to assets ratio

Rasio ini digunakan untuk mengukur seberapa jauh nilai seluruh aktiva bank dibiayai atau dananya diperoleh dari sumber-sumber utang jangka panjang. Rasio ini dapat dirumuskan sebagai berikut.

$$
\text { Long Term Debt to Assets Ratio }=\frac{\text { Utang Jangka Panjang }}{\text { Total Aktiva }} \times 100 \%
$$

\section{Hubungan Antar Variabel}

\section{Hubungan Loan to Deposit Ratio (LDR) Terhadap Return On Asset (ROA)}

Faktor ekspansi kredit yang ditunjukkan dengan rasio Loan to Deposit Ratio (LDR) sangat penting oleh bank dalam menjalankan fungsi intermediasinya dengan tujuan untuk memperoleh laba yang didapat dari selisih penerimaan bunga kredit dengan beban bunga simpanan. Loan to Deposit Ratio (LDR) yang semakin tinggi akan menunjukkan profitabilitas yang besar, karena kredit yang disalurkan oleh bank dapat dijalankan secara efektif. Sebaliknya semakin rendah Loan to Deposit Ratio (LDR) menunjukkan kurangnya efektivitas bank dalam menyalurkan kredit sehingga hilangnya kesempatan bank untuk memperoleh laba (Warsa dan Mustanda, 2016).

Penelitian sebelumnya yang dilakukan Lubis et al (2017), Prasetyo dan Darmayanti (2015), Raharjo et al (2014), dan Fadjar et al (2013) memperoleh hasil Loan to Deposit Ratio (LDR) berpengaruh signifikan terhadap Return On Asset (ROA).

\section{Hubungan Biaya Operasional dibandingkan Pendapatan Operasional Terhadap Return On Asset (ROA)}

Rasio yang sering disebut rasio efisiensi ini digunakan untuk mengukur kemampuan manajemen bank dalam mengendalikan biaya operasional terhadap pendapatan operasional.

Penelitian yang dilakukan Muin (2017), Ovami (2017), dan Dewi et al (2015) menyatakan bahwa Biaya Operasional dibandingkan Pendapatan Operasional (BOPO) berpengaruh negatif dan signifikan terhadap Return On Asset (ROA).

Hal diatas menunjukkan bahwa semakin tinggi nilai Biaya Operasional dibandingkan Pendapatan Operasional (BOPO) maka kegiatan operasional bank menjadi kurang efisien 
karena meningkatnya biaya operasional dan hal ini akan membuat Return On Asset (ROA) sebagai pengukur tingkat keuntungan mengalami penurunan. Sebaliknya, jika Biaya Operasional dibandingkan Pendapatan Operasional (BOPO) semakin kecil maka dapat disimpulkan kinerja suatu bank akan baik karena nilai Return On Asset (ROA) yang mengalami peningkatan.

\section{Hubungan Capital Adequacy Ratio (CAR) Terhadap Return On Asset (ROA)}

Capital Adequacy Ratio (CAR) mencerminkan modal perusahaan untuk menghasilkan laba. Semakin besar Capital Adequacy Ratio (CAR) maka semakin besar kesempatan bank dalam menghasilkan laba karena dengan modal yang besar, manajemen bank leluasa dalam menempatkan dananya kedalam aktivitas investasi yang menguntungkan (Anggreni dan Suardhika, 2014).

Semakin besar Capital Adequacy Ratio (CAR) maka semakin tinggi kemampuan permodalan bank dalam menjaga kemungkinan timbulnya risiko kerugian kegiatan usahanya sehingga kinerja bank juga meningkat. Sehingga Capital Adequacy Ratio (CAR) berpengaruh positif dan signifikan terhadap Return On Assets (ROA) (M. Muh. Sabir et al, 2012). Hasil yang serupa juga sama dengan penelitian yang dilakukan oleh Margaretha dan Letty (2017), Ovami (2017), dan Anggreni dan Suardhika (2014) yang memperoleh hasil bahwa Capital Adequacy Ratio (CAR) berpengaruh positif dan signifikan terhadap Return On Assets (ROA).

\section{Kerangka Pemikiran Teoritis}

Kerangka pemikiran teoritis pada penelitian ini terlihat pada Gambar 1.

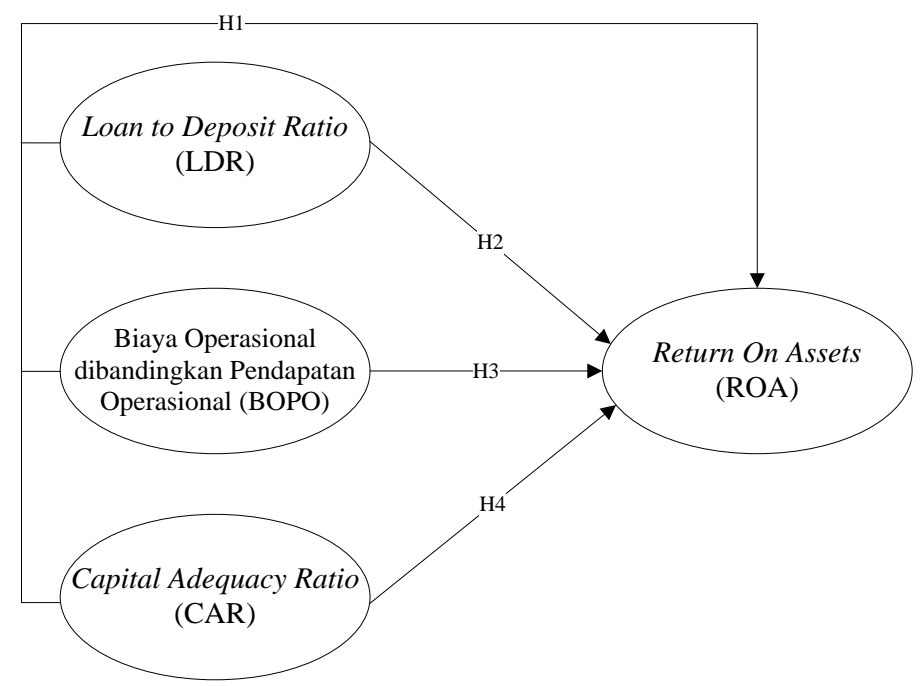

Gambar 1 Kerangka Pemikiran Teoritis 


\section{Hipotesis}

Hipotesis yang diajukan dalam penelitian ini adalah sebagai berikut:

H1 : Diduga Loan to Deposit Ratio (LDR), Biaya Operasional dibandingkan Pendapatan Operasional (BOPO), dan Capital Adequacy Ratio (CAR) secara simultan berpengaruh signifikan terhadap Return On Asset (ROA) pada PT Bank Maybank Indonesia Tbk periode 2010-2018.

H2 : Diduga Loan to Deposit Ratio (LDR) secara parsial berpengaruh signifikan terhadap Return On Asset (ROA) pada PT Bank Maybank Indonesia Tbk periode 2010-2018.

H3 : Diduga Biaya Operasional dibandingkan Pendapatan Operasional (BOPO) secara parsial berpengaruh signifikan terhadap Return On Asset (ROA) pada PT Bank Maybank Indonesia Tbk periode 2010-2018.

H4 : Diduga Capital Adequacy Ratio (CAR) secara parsial berpengaruh signifikan terhadap Return On Asset (ROA) pada PT Bank Maybank Indonesia Tbk periode 2010-2018.

\section{METODE PENELITIAN}

\section{Populasi dan Sampel}

Dalam penelitian ini target populasi adalah seluruh data laporan keuangan PT Bank Maybank Indonesia, sedangkan sampel yang diambil adalah Data dalam penelitian ini bersumber dari laporan triwulan dan laporan keuangan auditan PT Bank Maybank Indonesia periode 2010-2018.

\section{Jenis dan Sumber Data}

Jenis data dalam penelitian ini adalah data kuantitatif karena mengumpulkan data dan menganalisis data numerik dan non numerik yang diangkakan baik secara langsung maupun hasil pengolahan data. Sementara itu data yang digunakan dalam penelitian ini adalah data sekunder. Data sekunder biasanya berwujud dokumentasi atau data laporan yang sudah tersedia. Data dalam penelitian ini bersumber dari laporan triwulan dan laporan keuangan auditan PT Bank Maybank Indonesia periode 2010-2018 yang diperoleh dari website resmi perusahaan, situs resmi Otoritas Jasa Keuangan serta situs resmi Bank Indonesia.

\section{Metode Analisis}

\section{Uji Asumsi Klasik}

\section{Uji Normalitas}

Uji normalitas dilakukan untuk menguji apakah dalam model regresi, variabel dependen dan independen keduanya mempunyai distribusi yang normal atau tidak. Model regresi yang baik memiliki distribusi data normal (Ghozali, 2016:154). 


\section{Uji Multikolonieritas}

Ghozali (2016:103) menyatakan bahwa uji multikolonieritas bertujuan untuk menguji apakah model regresi ditemukan adanya korelasi antar variabel bebas (independen). Model regresi yang baik seharusnya tidak terjadi korelasi di antara variabel independen.

\section{Uji Heteroskedastisitas}

Uji heterokedastisitas mempunyai tujuan untuk menguji apakah dalam model regresi terjadi ketidaksamaan variance dan residual dari suatu pengamatan ke pengamatan yang lain. Jika variance dan residual dari satu pengamatan ke pengamatan lain adalah tetap, maka dapat disebut homoskedastisitas dan jika perbedaan yang terlihat maka disebut heteroskedastisitas (Ghozali, 2016:134).

\section{Uji Autokorelasi}

Menurut Ghozali (2016:107) uji autokorelasi bertujuan untuk menguji apakah dalam model regresi linear ada korelasi antara kesalahan pengganggu pada periode $t$ dengan kesalahan pengganggu pada periode t-1 (sebelumnya). Jika terjadi korelasi, maka dinamakan ada problem autokorelasi.

\section{Persamaan Model}

Metode analisis data yang digunakan didalam penelitian ini dilakukan dengan menggunakan analisis regresi. Ghozali (2016:93) menyatakan bahwa analisis regresi linier berganda digunakan untuk menganalisis pengaruh beberapa variabel bebas atau independen (X) terhadap satu variabel tidak bebas atau dependen variabel (Y) secara bersama-sama.

Dalam hubungannya dengan penelitian ini, variabel independen adalah Loan to Deposit Ratio (LDR) (X1), Biaya Operasional dibandingkan Pendapatan Operasional (BOPO) (X2), dan Capital Adequacy Ratio (CAR) (X3), sedangkan variabel dependen adalah Return On Asset (ROA) (Y1), sehingga persamaan regresi linier berganda adalah sebagai berikut:$$
\mathrm{ROA}=\alpha+\mathrm{b}_{1} \mathrm{LDR}+\mathrm{b}_{2} \mathrm{BOPO}+\mathrm{b}_{3} \mathrm{CAR}+\mathrm{e}
$$

\section{Uji Statistik F}

Uji F statistik digunakan untuk menguji apakah seluruh variabel-variabel dependen yang dimasukkan dalam model regresi secara bersama-sama berpengaruh terhadap variabel dependen (Ghozali, 2016:98).

\section{Uji Koefisien Determinasi $\left(\mathbf{R}^{2}\right)$}

Koefisien determinasi $\left(\mathrm{R}^{2}\right)$ digunakan untuk mengukur seberapa besar tingkat variabel independen yang digunakan dalam penelitian dapat menjelaskan variabel dependen (Goodness of Fit). Nilai terse.but menunjukkan seberapa dekat garis regresi yang kita estimasi dengan 
data yang sesungguhnya. Nilai koefisien determinasi adalah antara nol sampai satu dimana semakin mendekati satu maka model akan semakin baik. nilai $\mathrm{R}^{2}$ yang kecil berarti kemampuan variabel-variabel independen dalam menjelaskan variabel-variabel dependen sangat terbatas (Ghozali, 2016:97).

\section{Uji Statistik t}

Ghozali (2016:97), pengujian hipotesis dilakukan dengan cara menganalisis statistik regresi berganda karena variabel independen yang diuji terhadap variabel dependennya lebih dari satu variabel.

\section{HASIL DAN PEMBAHASAN}

\section{Statistik Deskriptif}

Hasil dari Uji Statistik Deskriptif pada penelitian ini dapat dilihat pada Tabel 1.

Tabel 1 Hasil Statistik Deskriptif

\begin{tabular}{|l|r|r|r|r|r|}
\hline & \multicolumn{1}{|c|}{$\mathrm{N}$} & Minimum & Maximum & Mean & $\begin{array}{c}\text { Std. } \\
\text { Deviation }\end{array}$ \\
\hline ROA & 36 &, 18 & 1,87 & 1,1736 &, 40158 \\
LDR & 36 & 80,58 & 100,64 & 88,1828 & 3,80598 \\
BOPO & 36 & 83,85 & 97,06 & 89,2356 & 3,87886 \\
CAR & 36 & 11,98 & 19,20 & 14,8931 & 2,24027 \\
Valid N (listwise) & 36 & & & & \\
\hline
\end{tabular}

Sumber : Data sekunder yang diolah dengan SPSS 20, 2019.

Berdasarkan Tabel 1, dapat diketahui bahwa nilai secara umum hasil statistik deskriptif dapat dikatakan berdistribusi baik, karena nilai rata-rata lebih besar dari nilai standar deviasi.

\section{Uji Asumsi Klasik}

\section{Uji Normalitas}

Hasil dari Uji Normalitas pada penelitian ini dapat dilihat pada Tabel 2.

Tabel 2 Hasil Uji Kolmogorov - Smirnov

\begin{tabular}{|c|c|c|}
\hline \multicolumn{3}{|c|}{ One-Sample Kolmogorov-Smirnov Test } \\
\hline & & $\begin{array}{l}\text { Unstandardized } \\
\text { Residual }\end{array}$ \\
\hline \multicolumn{2}{|l|}{$\mathrm{N}$} & 36 \\
\hline \multirow{2}{*}{ Normal Parameters ${ }^{\mathrm{a}, \mathrm{b}}$} & Mean & $0 \mathrm{E}-7$ \\
\hline & Std. Deviation & ,13380414 \\
\hline \multirow{3}{*}{$\begin{array}{l}\text { Most Extreme } \\
\text { Differences }\end{array}$} & Absolute &, 123 \\
\hline & Positive & 065 \\
\hline & Negative &,- 123 \\
\hline \multicolumn{2}{|l|}{ Kolmogorov-Smirnov Z } & ,741 \\
\hline \multicolumn{2}{|l|}{ Asymp. Sig. (2-tailed) } &, 643 \\
\hline \multicolumn{3}{|c|}{ a. Test distribution is Normal. } \\
\hline \multicolumn{3}{|c|}{ b. Calculated from data. } \\
\hline
\end{tabular}

Sumber : Data sekunder yang diolah dengan SPSS 20, 2019. 
Berdasarkan Tabel 2, diketahui nilai signifikansi 0,643 lebih besar dari 0,05. Hal ini menunjukkan bahwa data dalam penelitian ini berdistribusi normal.

\section{Uji Multikolonieritas}

Hasil dari Uji multikolonieritas dapat dilihat pada Tabel 3.

Tabel 3

Hasil Uji Multikolonieritas

\begin{tabular}{|c|c|c|c|}
\hline \multicolumn{4}{|c|}{$\begin{array}{c}\text { Coefficients }^{\mathbf{a}} \\
\end{array}$} \\
\hline \multirow{2}{*}{\multicolumn{2}{|c|}{ Model }} & \multicolumn{2}{|c|}{ Collinearity Statistics } \\
\hline & & Tolerance & VIF \\
\hline \multirow{4}{*}{1} & (Constant) & & \\
\hline & LDR & ,718 & 1,394 \\
\hline & BOPO & ,777 & 1,286 \\
\hline & CAR & ,579 & 1,727 \\
\hline
\end{tabular}

Sumber : Data sekunder yang diolah dengan SPSS 20, 2019.

Berdasarkan Tabel 3, tidak ada variabel independen yang memiliki nilai Tolerance $\leq 0,10$. Begitu juga dengan hasil perhitungan nilai VIF, tidak ada variabel independen yang memiliki nilai $\mathrm{VIF} \geq 10$. Sehingga dapat disimpulkan bahwa tidak terjadi multikolonieritas.

\section{Uji Heteroskedastisitas}

Hasil dari Uji Heteroskedastisitas dapat dilihat pada Tabel 4.

Tabel 4 Hasil Uji Glejser

\begin{tabular}{|c|c|c|c|c|c|c|}
\hline \multicolumn{7}{|c|}{ Coefficients $^{a}$} \\
\hline \multirow{2}{*}{\multicolumn{2}{|c|}{ Model }} & \multicolumn{2}{|c|}{$\begin{array}{l}\text { Unstandardized } \\
\text { Coefficients }\end{array}$} & \multirow{2}{*}{$\begin{array}{l}\text { Standardized } \\
\text { Coefficients } \\
\text { Beta }\end{array}$} & \multirow[t]{2}{*}{$\mathrm{T}$} & \multirow[t]{2}{*}{ Sig. } \\
\hline & & $\mathrm{B}$ & Std. Error & & & \\
\hline \multirow{4}{*}{1} & (Constant) & ,323 &, 520 & & ,621 & ,539 \\
\hline & LDR &,- 001 & ,005 &,- 031 &,- 150 & ,882 \\
\hline & $\mathrm{BOPO}$ &, 000 & ,004 &,- 021 &,- 108 & ,915 \\
\hline & CAR &,- 008 & ,009 &,- 210 &,- 928 & ,361 \\
\hline
\end{tabular}

Sumber : Data sekunder yang diolah dengan SPSS 20, 2019.

Berdasarkan Tabel 4, dapat dilihat bahwa semua nilai signifikansi (sig.) variabel independen adalah lebih besar dari 0,05. Hal ini menunjukkan bahwa dalam penelitian ini tidak terjadi heteroskedastisitas.

\section{Uji Autokorelasi}

Hasil dari Uji Autokorelasi dapat dilihat pada Tabel 5. 
Tabel 5 Hasil Uji Durbin-Watson

\begin{tabular}{|l|r|r|r|r|r|}
\hline \multicolumn{7}{|c|}{ Model Summary $^{\mathbf{b}}$} \\
\hline Model & $\mathrm{R}$ & R Square & $\begin{array}{c}\text { Adjusted R } \\
\text { Square }\end{array}$ & $\begin{array}{c}\text { Std. Error of the } \\
\text { Estimate }\end{array}$ & $\begin{array}{c}\text { Durbin- } \\
\text { Watson }\end{array}$ \\
\hline 1 &, $943^{\mathrm{a}}$ &, 889 &, 879 &, 13994 &, 992 \\
\hline \multicolumn{7}{|l}{ a. Predictors: (Constant), CAR, BOPO, LDR } \\
\hline
\end{tabular}

Sumber : Data sekunder yang diolah dengan SPSS 20, 2019.

Berdasarkan Tabel 5 hasil Uji Durbin-Watson (uji DW) menunjukkan nilai sebesar 0,992. Hasil ini menunjukkan bahwa nilai DW berada diantara -2 dan +2 atau $-2 \leq \mathrm{DW} \leq+2$ sehingga dapat disimpulkan bahwa persamaan regresi terbebas dari autokorelasi.

\section{Persamaan Model}

Penentuan pengaruh variabel independen yaitu Loan to Deposit Ratio (LDR), Biaya Operasional dibandingkan Pendapatan Operasional (BOPO), dan Capital Adequacy Ratio (CAR) terhadap Return On Asset (ROA) sebagai variabel dependen, peneliti menggunakan SPSS 20 dapat dilihat pada Tabel 6.

Tabel 6 Hasil Uji Analisis Regresi Linier Berganda

\begin{tabular}{|c|c|c|c|}
\hline \multicolumn{4}{|c|}{ Coefficients $^{\mathbf{a}}$} \\
\hline \multirow{2}{*}{\multicolumn{2}{|c|}{ Model }} & \multicolumn{2}{|c|}{ Unstandardized Coefficients } \\
\hline & & B & Std. Error \\
\hline \multirow{4}{*}{1} & (Constant) & 12,700 & ,833 \\
\hline & LDR &,- 013 & 007 \\
\hline & $\mathrm{BOPO}$ &,- 107 & 007 \\
\hline & CAR &,- 060 &, 014 \\
\hline
\end{tabular}

Sumber : Data sekunder yang diolah dengan SPSS 20, 2019.

Berdasarkan Tabel 6, dapat disusun persamaan regresi linier berganda sebagai berikut:

$$
\text { ROA = 12,700 - 0,013 LDR - 0,107 BOPO - 0,060 CAR + e }
$$

Berdasarkan persamaan regresi di atas, dapat diintrepretasikan sebagai berikut:

\section{Konstanta $=\mathbf{1 2 , 7 0 0}$}

Konstanta sebesar 12,700 menunjukkan bahwa jika variabel-variabel independen yaitu LDR, BOPO, dan CAR diasumsikan bernilai konstan, maka variabel dependen (ROA) mempunyai nilai positif sebesar 12,700 .

\section{Koefisien variabel $L D R=\mathbf{- 0 , 0 1 3}$}

Hal ini menunjukkan bahwa variabel LDR berpengaruh negatif terhadap ROA. Hal ini berarti setiap terjadi peningkatan pada variabel LDR sebesar 1 (satu) satuan, maka ROA akan mengalami penurunan sebesar 0,013, dengan asumsi variabel lainnya tetap. 


\section{Koefisien variabel $\mathrm{BOPO}=\mathbf{- 0 , 1 0 7}$}

Hal ini menunjukkan bahwa variabel BOPO berpengaruh negatif terhadap ROA. Hal ini berarti setiap terjadi peningkatan pada variabel BOPO sebesar 1 (satu) satuan, maka ROA akan mengalami penurunan sebesar 0,107, dengan asumsi variabel lainnya tetap.

4. Koefisien variabel $\mathrm{CAR}=\mathbf{- 0 , 0 6 0}$

Hal ini menunjukkan bahwa variabel CAR berpengaruh negatif terhadap ROA. Hal ini berarti setiap terjadi peningkatan pada variabel CAR sebesar 1 (satu) satuan, maka ROA akan mengalami penurunan sebesar 0,060, dengan asumsi variabel lainnya tetap.

\section{Uji Statistik F}

Hasil dari Uji Statistik F dapat dilihat pada Tabel 7.

Tabel 7 Hasil Uji Statistik F

\begin{tabular}{|c|c|c|c|c|c|c|}
\hline \multicolumn{7}{|c|}{ ANOVA $^{\mathbf{a}}$} \\
\hline \multicolumn{2}{|c|}{ Model } & $\begin{array}{l}\text { Sum of } \\
\text { Squares }\end{array}$ & Df & $\begin{array}{l}\text { Mean } \\
\text { Square }\end{array}$ & $\mathrm{F}$ & Sig. \\
\hline \multirow{3}{*}{1} & Regression & 5,018 & 3 & 1,673 & 85,415 &, $000^{b}$ \\
\hline & Residual &, 627 & 32 &, 020 & & \\
\hline & Total & 5,644 & 35 & & & \\
\hline \multicolumn{7}{|c|}{ a. Dependent Variable: ROA } \\
\hline
\end{tabular}

Sumber : Data sekunder yang diolah dengan SPSS 20, 2019.

Berdasarkan Tabel 7 dihasilkan $F_{\text {hitung }}=85,415>F_{\text {tabel }}=2,90$ atau signifikansi $=0,000<$ 0,05 , yang berarti terdapat pengaruh yang signifikan antara variabel LDR, BOPO, dan CAR secara simultan terhadap ROA.

Dengan demikian hipotesis 1 (satu) yang menyatakan "Diduga Loan to Deposit Ratio (LDR), Biaya Operasional dibandingkan Pendapatan Operasional (BOPO), dan Capital Adequacy Ratio (CAR) secara simultan berpengaruh signifikan terhadap Return On Asset (ROA) pada PT Bank Maybank Indonesia Tbk periode 2013-2018” dinyatakan diterima.

\section{Uji Koefisien Determinasi $\left(\mathbf{R}^{2}\right)$}

Hasil dari Uji Koefisien Determinasi $\left(\mathrm{R}^{2}\right)$ dapat dilihat pada Tabel 8.

Tabel 8 Hasil Uji Koefisien Determinasi $\left(\mathbf{R}^{2}\right)$

\begin{tabular}{|l|r|r|r|r|}
\hline \multicolumn{5}{|c|}{ Model Summary } \\
\hline Model & $\mathrm{R}$ & R Square & $\begin{array}{c}\text { Adjusted R } \\
\text { Square }\end{array}$ & $\begin{array}{c}\text { Std. Error of the } \\
\text { Estimate }\end{array}$ \\
\hline 1 &, $943^{\mathrm{a}}$ &, 889 &, 879 &, 13994 \\
\hline \multicolumn{5}{|c|}{ a. Predictors: (Constant), CAR, BOPO, LDR } \\
\hline
\end{tabular}

Sumber : Data sekunder yang diolah dengan SPSS 20, 2019. 
Berdasarkan Tabel 8 dihasilkan nilai Adjusted $R$ Square sebesar 0,879 atau 87,9 \%. Artinya variabel LDR, BOPO, dan CAR memberikan kontribusi pengaruh terhadap ROA sebesar $87,9 \%$. Sedangkan sisanya sebesar $12,1 \%$ dipengaruhi oleh variabel lain yang tidak diteliti dalam penelitian ini.

\section{Uji Statistik t}

Hasil dari Uji Statistik t dapat dilihat pada Tabel 9.

Tabel 9 Hasil Uji Statistik t

\begin{tabular}{|c|c|c|c|c|c|c|}
\hline \multicolumn{7}{|c|}{ Coefficients $^{\mathbf{a}}$} \\
\hline \multicolumn{2}{|c|}{ Model } & \multicolumn{2}{|c|}{$\begin{array}{l}\text { Unstandardized } \\
\text { Coefficients } \\
\end{array}$} & $\begin{array}{c}\begin{array}{c}\text { Standardized } \\
\text { Coefficients }\end{array} \\
\text { Beta }\end{array}$ & $\mathrm{T}$ & Sig. \\
\hline \multirow{4}{*}{1} & (Constant) & 12,700 & ,833 & & 15,239 &, 000 \\
\hline & LDR &,- 013 & ,007 &,- 120 & $-1,730$ & ,093 \\
\hline & BOPO &,- 107 & ,007 & $-1,029$ & $-15,405$ & ,000 \\
\hline & CAR &,- 060 & ,014 &,- 337 & $-4,358$ &, 000 \\
\hline
\end{tabular}

Sumber : Data sekunder yang diolah dengan SPSS 20, 2019.

Berdasarkan Tabel 9 hasil uji t, dapat dilakukan pembuktian hipotesis terhadap masingmasing variabel sebagai berikut:

1. $\mathrm{t}$ hitung untuk variabel $\mathrm{LDR}=-1,730<\mathrm{t}$ tabel $=-2,03693$ atau signifikansi $=0,093>$ 0,05 , yang berarti tidak terdapat pengaruh yang signifikan antara LDR secara parsial terhadap ROA. Dengan demikian hipotesis 2 (dua) yang menyatakan "Diduga Loan to Deposit Ratio (LDR) secara parsial berpengaruh signifikan terhadap Return On Asset (ROA) pada PT Bank Maybank Indonesia Tbk periode 2010-2018”, ditolak.

2. $\mathrm{t}$ hitung untuk variabel $\mathrm{BOPO}=-15,405>\mathrm{t}$ tabel $=-2,03693$ atau signifikansi $=0,000<$ 0,05 , yang berarti terdapat pengaruh yang signifikan antara BOPO secara parsial terhadap ROA. Dengan demikian hipotesis 3 (tiga) yang menyatakan "Diduga Biaya Operasional dibandingkan Pendapatan Operasional (BOPO) secara parsial berpengaruh signifikan terhadap Return On Asset (ROA) pada PT Bank Maybank Indonesia Tbk periode 20102018", diterima.

3. $\mathrm{t}$ hitung untuk variabel $\mathrm{CAR}=-4,358>\mathrm{t}$ tabel $=-2,03693$ atau signifikansi $=0,000<$ 0,05 , yang berarti terdapat pengaruh yang signifikan antara CAR secara parsial terhadap ROA. Dengan demikian hipotesis 4 (empat) yang menyatakan "Diduga Capital Adequacy Ratio (CAR) secara parsial berpengaruh signifikan terhadap Return On Asset (ROA) pada PT Bank Maybank Indonesia Tbk periode 2010-2018”, diterima. 


\section{Pembahasan}

\section{Pengaruh Loan to Deposit Ratio (LDR) terhadap Return On Asset (ROA)}

Berdasarkan Tabel 9 diperoleh hasil bahwa nilai t hitung untuk variabel LDR $=-1,730<$ $\mathrm{t}$ tabel $=-2,03693$ atau signifikansi $=0,093>0,05$ dengan arah koefisien regresi negatif $\left(b_{1}=\right.$ -0,013), sehingga LDR secara parsial berpengaruh negatif dan tidak signifikan terhadap ROA.

Arah negatif dari variabel LDR menunjukkan bahwa semakin besar LDR maka ROA akan menurun. Hal ini sejalan dengan teori yang dikemukakan oleh Dendawijaya (2009:117) yang menyatakan bahwa rasio LDR juga merupakan indikator kerawanan dari suatu bank. Artinya jika rasio LDR terlalu besar, maka likuiditas bank menurun sehingga bank tidak mampu memenuhi kewajiban jangka pendeknya. Disisi lain kinerja bank juga akan menurun sebab masyarakat akan kehilangan kepercayaan untuk menyimpan uang di bank tersebut.

Hasil penelitian ini mendukung penelitian terdahulu yang dilakukan oleh Muin (2017), Ovami (2017) dan Hutagalung et al (2013) yang menyatakan bahwa Loan to Deposit Ratio (LDR) berpengaruh negatif dan tidak signifikan terhadap Return On Asset (ROA).

\section{Pengaruh Biaya Operasional dibandingkan Pendapatan Operasional (BOPO) terhadap Return On Asset (ROA)}

Berdasarkan Tabel 9 diperoleh hasil bahwa nilai thitung untuk variabel $\mathrm{BOPO}=-15,405$ $>\mathrm{t}$ tabel $=-2,03693$ atau signifikansi $=0,000<0,05$ dengan arah koefisien regresi negatif $\left(\mathrm{b}_{2}\right.$ $=-0,107)$, sehingga BOPO secara parsial berpengaruh negatif dan signifikan terhadap ROA.

Arah negatif menunjukkan bahwa semakin tinggi nilai Biaya Operasional dibandingkan Pendapatan Operasional (BOPO) akan membuat Return On Asset (ROA) mengalami penurunan. Sebaliknya, jika Biaya Operasional dibandingkan Pendapatan Operasional (BOPO) semakin kecil maka Return On Asset (ROA) yang mengalami peningkatan.

Hal ini sesuai dengan konsep teori yang diungkapkan oleh Taswan (2010:167), yang mengemukakan bahwa semakin tinggi efisiensi operasional maka semakin tidak efisien bank, dengan kata lain, jika biaya operasional yang dikeluarkan tinggi maka laba yang diperoleh lebih kecil sehingga menyebabkan rentabilitas menurun. Jika biaya operasional yang dikeluarkan rendah, maka laba yang diperoleh lebih besar sehingga menyebabkan rentabilitas meningkat.

Hasil penelitian ini mendukung penelitian terdahulu yang dilakukan oleh Lubis et al (2017), Muin (2017), Ovami (2017), Dewi et al (2015), Prasetyo dan Darmayanti (2015), Raharjo (2014), Hutagalung et al (2013), dan Sudiyatno dan Fatmawati (2013) yang juga mendapatkan hasil yang serupa yaitu Biaya Operasional dibandingkan Pendapatan Operasional (BOPO) berpengaruh negatif dan signifikan terhadap Return On Asset (ROA). 


\section{Pengaruh Capital Adequacy Ratio (CAR) terhadap Return On Asset (ROA)}

Berdasarkan Tabel 9 diperoleh hasil bahwa nilai t hitung untuk variabel CAR $=-4,358>$ $\mathrm{t}$ tabel $=-2,03693$ atau signifikansi $=0,000<0,05$ dengan arah koefisien regresi negatif $\left(b_{3}=\right.$ -0,060), sehingga CAR secara parsial berpengaruh negatif dan signifikan terhadap ROA.

Arah pengaruh negatif menunjukkan bahwa semakin tinggi nilai CAR, mengakibatkan ROA semakin rendah. Menurut Muin (2017), semakin tinggi kemampuan permodalan bank dalam menjaga kemungkinan timbulnya risiko kerugian kegiatan usahanya namun belum tentu secara nyata berpengaruh terhadap peningkatan ROA. Namun disisi lain, CAR yang tinggi dapat mengurangi kemampuan bank dalam melakukan ekspansi usahanya karena semakin besarnya cadangan modal yang digunakan untuk menutupi risiko kerugian. Terhambatnya ekspansi usaha akibat tingginya CAR yang pada akhirnya akan mempengaruhi kinerja keuangan bank tersebut. Hasil penelitian ini mendukung penelitian terdahulu yang dilakukan oleh Lubis et al (2017), Muin (2017), dan Raharjo (2014) berpengaruh negatif dan signifikan terhadap Return On Asset (ROA).

\section{PENUTUP}

Berdasarkan hasil analisis dan pembahasan sebelumnya, maka dapat diambil kesimpulan sebagai berikut:

1. Variabel Loan to Deposit Ratio (LDR), Biaya Operasional dibandingkan Pendapatan Operasional (BOPO), dan Capital Adequacy Ratio (CAR) secara simultan berpengaruh signifikan terhadap Return On Asset (ROA) pada PT Bank Maybank Indonesia Tbk periode 2013-2018.

2. Variabel Loan to Deposit Ratio (LDR) secara parsial berpengaruh negatif dan tidak signifikan terhadap Return On Asset (ROA) pada PT Bank Maybank Indonesia Tbk periode 2010-2018.

3. Variabel Biaya Operasional dibandingkan Pendapatan Operasional (BOPO) secara parsial berpengaruh negatif dan signifikan terhadap Return On Asset (ROA) pada PT Bank Maybank Indonesia Tbk periode 2010-2018.

4. Variabel Capital Adequacy Ratio (CAR) secara parsial berpengaruh negatif dan signifikan terhadap Return On Asset (ROA) pada PT Bank Maybank Indonesia Tbk periode 2010-2018.

\section{Keterbatasan Penelitian}

1. Obyek yang digunakan dalam penelitian ini terbatas pada PT Bank Maybank Indonesia Tbk. 
2. Variabel-variabel independen yang digunakan dalam pnelitian ini terbatas hanya 3 (tiga) variabel, yaitu Loan to Deposit Ratio (LDR), Biaya Operasional dibandingkan Pendapatan Operasional (BOPO), dan Capital Adequacy Ratio (CAR) sedangkan masih ada variabel lain yang tidak digunakan dalam penelitian ini untuk memprediksi kinerja keuangan bank.

\section{Saran}

Berdasarkan keterbatasan pada penelitian ini, maka saran untuk penelitian mendatang yang diusulkan antara lain:

1. Bagi peneliti selanjutnya diharapkan mampu untuk menambahkan objek penelitian yang lebih banyak, sehingga tidak terbatas pada satu objek saja.

2. Bagi peneliti selanjutnya diharapkan dapat meneliti dengan variabel-variabel lain di luar Loan to Deposit Ratio (LDR), Biaya Operasional dibandingkan Pendapatan Operasional (BOPO), dan Capital Adequacy Ratio (CAR) agar memperoleh hasil ang lebih bervariatif yang dapat menggambarkan hal-hal apa saja yang dapat berpengaruh terhadap kinerja keuangan perbankan.

\section{DAFTAR PUSTAKA}

Anggreni, Made Ria dan Suardhika, I Made Sadha. 2014. "Pengaruh Dana Pihak Ketiga, Kecukupan Modal, Risiko Kredit, dan Suku Bunga Kredit Pada Profitabilitas”. E-Jurnal Akuntansi Universitas Udayana. ISSN 2302-8556.

Bank Indonesia. 1998. Undang-Undang Republik Indonesia No. 10 tentang Perbankan. http://www.bi.go.id.

Bank Indonesia. 2011. Lampiran 14 Surat Edaran Bank Indonesia No. 13/30/DPNP. http://www.bi.go.id.

Dendawijaya, Lukman. 2009. Manajemen Perbankan. Jakarta: Ghalia Indonesia.

Dewi, Luh Prima, Nyoman Trisna Herawati, Luh Gede Erni Sulindawati. 2015. "Analisis Pengaruh NIM, BOPO, LDR, dan NPL Terhadap Profitabilitas (Studi Kasus Pada Bank Umum Swasta Nasional yang Terdaftar Pada Bursa Efek Indonesia Periode 2009-2013)". E-Journal S1 Ak. Universitas Pendidikan Ganesha. Volume 3, Nomor 1.

Fadjar, Aris, Hedwigis Esti R., Tri Prihatini EKP. 2013. “Analisis Faktor Internal dan Eksternal Bank yang Mempengaruhi Profitabilitas Bank Umum di Indonesia”. Journal of Management and Business Review. Volume 10, Nomor 1. 
Hutagalung, Esther Novelina, Djumahir, Kusuma Ratnawati. 2013. “Analisa Rasio Keuangan Terhadap Kinerja Bank Umum di Indonesia”. Jurnal Aplikasi Manajemen. Volume 11, Nomor 1. ISSN 1693-5241.

Ghozali, Imam. 2016. Aplikasi Analisis Multivariate dengan Program IBM SPSS Edisi 8. Semarang: Badan Penerbit UNDIP.

Infobank. 2018. “Laba Maybank Indonesia Turun 6,58\% Pada Semester-I 2018”. 03 September 2018.

Kasmir. 2010. Analisis Laporan Keuangan. Jakarta: Rajawali Pers.

Kuncoro, Mudrajad dan Suhardjono. 2011. Manajemen Perbankan Teori dan Aplikasi. Yogyakarta: BPFE.

Lubis, Fadhiah Annisa, Deannes Isynuwardhana, Vaya Juliana Dillak. 2017. "Pengaruh Loan to Deposit Ratio (LDR), Non Performing Loan (NPL), Capital Adequacy Ratio (CAR), Net Interest Margin (NIM), Biaya Operasional Pendapatan Operasional (BOPO) Terhadap Return On Asset (Studi Kasus pada Perusahaan Perbankan yang Terdaftar di Bursa Efek Indonesia Tahun 2012-2015)”. E-Proceeding of Management. Volume 4, Nomor 3. ISSN 2355-9357.

M. Muh. Sabir, Muhammad Ali, Abd. Hamid Habbe. 2012. "Pengaruh Rasio Kesehatan Bank Terhadap Kinerja Keuangan Bank Umum Syariah dan Bank Konvensional di Indonesia”. Jurnal Analisis. Volume 1, Nomor 1. ISSN 2303-1001.

Margaretha, Farah dan Letty. 2017. "Faktor-Faktor yang Mempengaruhi Kinerja Keuangan Perbankan Indonesia”. Manajemen Keuangan. Volume 6, Nomor 2. ISSN 2089-3477. Muin, Sri Adrianti. 2017. "Analisis Faktor-Faktor yang Mempengaruhi Rentabilitas Pada PT Bank Rakyat Indonesia (Persero) Tbk. Periode 2011-2016”. Jurnal Economic. Volume 5 , Nomor 2 .

Munawir. 2010. Analisa Laporan Keuangan. Yogyakarta: Liberty.

Ovami, Debbi Chyntia. 2017. "Faktor-Faktor Yang Mempengaruhi Kinerja Keuangan Bank Konvensional Pada Bursa Efek Indonesia”. Jurnal Konsep Bisnis dan Manajemen. Volume 4, Nomor 1. ISSN 2407-2648.

Prasetyo, Dwi Agung dan Darmayanti, Ni Putu Ayu. 2015. "Pengaruh Risiko Kredit, Likuiditas, Kecukupan Modal, dan Efisiensi Operasional Terhadap Profitabilitas Pada BT BPD Bali”. E-Jurnal Manajemen Unud. Volume 4, Nomor 9. ISSN 2302-8912.

Raharjo, Dwi Priyanto Agung, Bambang Setiaji, Syamsudin. 2014. "Pengaruh Rasio CAR, NPL, LDR, BOPO, dan NIM Terhadap Kinerja Bank Umum di Indonesia”. Jurnal Ekonomi Manajemen Sumber Daya. Volume 15, Nomor 2. 
Sudiyatno, Bambang dan Fatmawati, Asih. 2013. "Pengaruh Risiko Kredit dan Efisiensi Operasional Terhadap Kinerja Bank (Studi Empirik Pada Bank yang Terdaftar di Bursa Efek Indonesia)”. Jurnal Organisasi dan Manajemen. Volume 9, Nomor 1.

Taswan. 2006. Manajemen Perbankan: Konsep, Teknik, dan Aplikasi. Yogyakarta: UPP STIM YKPN.

Warsa, Ni Made Inten Uthami Putri dan Mustanda, I Ketut. 2016. "Pengaruh CAR, LDR, dan NPL Terhadap ROA Pada Sektor Perbankan di Bursa Efek Indonesia”. E-Jurnal Manajemen Unud. Volume 5, Nomor 5. ISSN 2302-2870.

Wiyono, Gendro. 2011. Merancang Penelitian Bisnis dengan Alat Analisis SPSS 17.0 \& SmartPLS 2.0. Yogyakarta: Unit Penerbit dan Percetakan STIM TKPM.

www.maybank.co.id

www.ojk.go.id 